RÉKASINÉ AdAMKó Adrienn

DOI: 10.15170/DIKE.2017.01.01.07

PhD-hallgató

jogi előadó

Magyar Országos Közjegyzői Kamara Jogi Iroda

\title{
Aki megment egy életet: az örökbefogadás az osztrák és a magyar magánjog rendszerében a polgári korszakban
}

Who save a life: Adoption in Austrian and Hungarian privat law in the bourgeois era

The main aim of this study is to introduce the reasons and conditions of the adoption, comparing the Austrian and Hungarian law. This study takes as a basis the Austrian civil code of 1811, the Hungarian statute of tutelage of 1877, the Draft of the Hungarian private law code of 1928 and archived documents between 1872 and 1910.

Keywords: adoption, inheritance, Austrian civil code of 1811, the Draft of the Hungarian private law code of 1928

„A gyermekek nem pótolják a szerelmet, nem belyettesitik egy összetört élet célját, nem tárgyak, amelyek rendeltetése az. életünk üres részének megtöltése, felelösséget és nehéz feladatot jelentenek, a gyermekek nem a szülök játékszerei, sem pedig a kielégületlen ambicióik pótolói."

Simone de Beauvoir

\section{A kutatás tárgya és forrásai}

A tanulmány célja az örökbefogadás, mint jogintézmény létrejöttét elősegitő tényezők, körülmények feltárása, a jogintézmény megjelenésével a folyamatosan változó célok bemutatása, valamint összehasonlítása a magyar és az osztrák magánjog rendszerében. E tanulmány az Osztrák Polgári Törvénykönyvre (a továbbiakban: OPTK) és a magyar magánjogi törvénykönyv 1928-ban országgyúlés elé terjesztett javaslatára (a továbbiakban: MTJ) épül, valamint a Magyar Nemzeti Levéltár Baranya Megyei Levéltárában (a továbbiakban: MNL BML) az 1872-tôl 1910-ig fennmaradt levéltári iratok kutatásán alapul. A tanulmány bemutatja, hogy az OPTK milyen hatást gyakorolt a hazai szabályozás alakulására az örökbefogadás területén az anyaországban, és a Korona társországaiban az árván maradt gyermekek családban történő nevelkedése, a magtalan családok gyermekhez jutása érdekében.

Az örökbefogadás évezredes jogintézmény: nem csupán a római jog, hanem - valamilyen formában - a keleti jogrendszerek is ismerték. Eredeti célja az volt, hogy az örökbefogadott részesüljön az örökbefogadó vagyonában, vagyis az, hogy törvényes örökössé váljon. Az újabb polgári jogfelfogás az örökbefogadó és az örökbefogadott közötti családi kapcsolat létrehozásában látta az örökbefogadás célját, teljes családi kapcsolatot létrehozva az örökbefogadott és az 
örökbefogadó családja között. ${ }^{1}$ A megfogalmazott célok a társadalmi fejlődés során változtak, azonban az sem volt kizárt és nem kizárt ma sem, hogy párhuzamosan több célt is szolgáljon. ${ }^{2}$ Bacsó Jenô szerint az örökbefogadás nemcsak a magyar, hanem a legtöbb külföldi jogban is régóta fennálló olyan intézmény, amely tartalma az idôk folyamán a nemzetségfenntartó, vagyont egy kézben egyesítő szerződésből a gyermek nevelésének és gondozásának egyik hatékony eszközévé vált. ${ }^{3}$ Erre utal egyébként az intézmény neve is: a latin adoptio befogadás, rokonná fogadás, orosz uszinovlenyij vagy udocserenyij fiúvá vagy leánnyá fogadás, német Annabme an Kindes Stat gyermekké fogadás. Csupán a magyar elnevezés (örökbefogadás) utal a rokonná tétel mellett nyíltan arra, hogy a befogadás az örökössé tételt tűzte ki célul. ${ }^{4}$

Az ókorban, a római jog szerint az örökbefogadás elsődleges rendeltetése a család megerôsítése volt, ha arra egyéb lehetőség nem adatott meg (imitatio naturae). Akkoriban kizárólag nagykorú személyt lehetett örökbe fogadni. Célja egyfelől a családi név és többnyire kultikus feladatok továbbvitele, másfelől a hagyaték biztosítása, nemzetséghez való visszakerülés ellen. Az örökbefogadás öröklési jogi dominanciája sokáig még azután is megmaradt, hogy megjelent a szabad végrendelkezés.

Speciális célként jelent meg például a rabszolga-felszabadítás. ${ }^{5}$ A római jog az örökbefogadás két formáját ismerte: az arrogatiot valamint az adoptiot, azzal, hogy mindkét esetben az örökbefogadók csak önjogú római polgárok, családfők lehettek. Az arrogatio az önjogú személy, az adoptio valamely családfő hatalma alatt álló személy örökbefogadását jelentette. Az adoptio eredményezhetett atyai hatalmat (adoptio plena) vagy csak öröklési jogot (adoptio minus plena). Később nôk is fogadhattak örökbe, de ekkor is csak öröklési jogot biztosított az örökbefogadás. ${ }^{6}$

1. kép: Árvaházi reggeli (Vasárnapi Újság 1883)

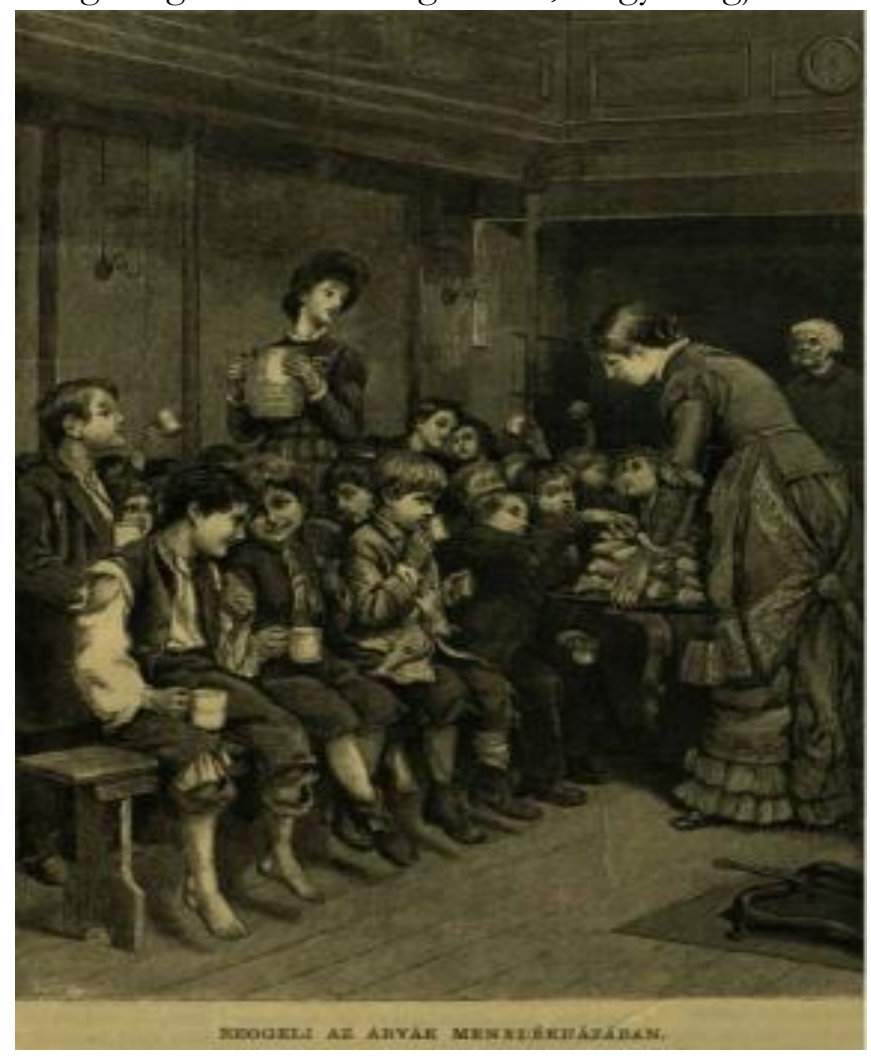

A hagyományos társadalom gyermekhez való viszonyát a mai ember számára nehezen feloldható ellentmondás jellemezte. A gyermeket Isten (illetve a kereszténység elótti korban a nem zsidó népeknél: az istenek) ajándékának tekintették. E családközpontú világképpel szoros

\footnotetext{
1 JobBÁGYI, Személyi és Családi Jog 11.

${ }^{2}$ KŐRÖS, A családjog kézikönyve I. 445.

${ }^{3}$ BACSÓ, Az örökbefogadás 17.

4 BACsÓ, Az örökbefogadás 609-616.

${ }^{5}$ FÓNAGY, Az örökbefogadás https://orokbe.hu/2014/06/30/az-orokbefogadas-tortenelmi-latoszogbol

${ }^{6}$ KATONÁNÉ PEHR, Az Örökbefogadás 32.
} 
összefüggésben állt az ősök tisztelete, sőt kultusza (aminek egyes elemeit, a maga képére formálva a kereszténység is fenntartotta). Ahhoz pedig, hogy az ember maga is bevonulhasson a tisztelettel őrzött emlékű ősök közé, neki is utódokra volt szüksége.

A család, a név fenntartásán túl a kétkezi munkát végzô túlnyomó többség - parasztok, iparosok - szemében a gyermek a családi gazdaság munkaerejeként is értéknek számított. A gyermekszülés illetve gyermeknemzés tehát az ember legfőbb élethivatása betöltésének számított. A gyermektelenségre - legyen az meddőség vagy gyermekhalálok következménye - „Isten veréseként” tekintettek, s gyakran valamely bűn megérdemelt büntetésének értelmezték. Ha minden erőfeszítés ellenére sem sikerült a gyermekvállalás, örökbe fogadtak valakit, mert - magyar paraszti szólással „nem akarták kutyára hagyni a nevüket.” A 20. század előtt gyakori volt a család felbomlása az egyik vagy mindkét szülő halála miatt, még mielőtt az összes gyermek elérte a felnőttkort. Ilyenkor a kicsi gyermeket az idősebb testvér, a nagyszülők vagy más rokonok nevelték. A megözvegyült szülők többnyire újraházasodtak, így sok családban találkozunk mostohatestvérekkel és mostohaszülővel. (Ezt tükrözik vissza a népmesék is, amelyeknek gyakori szereplője lett a gonosz mostoha.)

Ha a részletek változtak is az idők folyamán, az örökbefogadás lényege a polgári kor előtt ugyanaz volt: az egyenes ági leszármazottal nem rendelkezők elsősorban törvényes örökösről kívántak gondoskodni, hogy biztosítsák a család nevének fennmaradását, és rendezzék vagyonuk sorsát a haláluk utáni időre. ${ }^{8} \mathrm{Az}$ atya halálával megárvult gyermekekrôl eleinte az osztatlan vagyonközösségben élő férfi rokonok gondoskodtak és jártak el képviselőként. Minthogy még sokszor a 15. században is fennmaradt az osztály után a testvérek, unokatestvérek vagyonközössége, a gyámság intézménye meglehetősen későn, csak a 18-19. században jelent meg illetve terjedt el. A gyámi tisztet a nem törvényes korú árva felett a legközelebbi atyai ági férfi rokon vagy rokonok látták el, akik a gyermek után öröklésre voltak jogosultak. ${ }^{9}$ Az örökbefogadás tehát

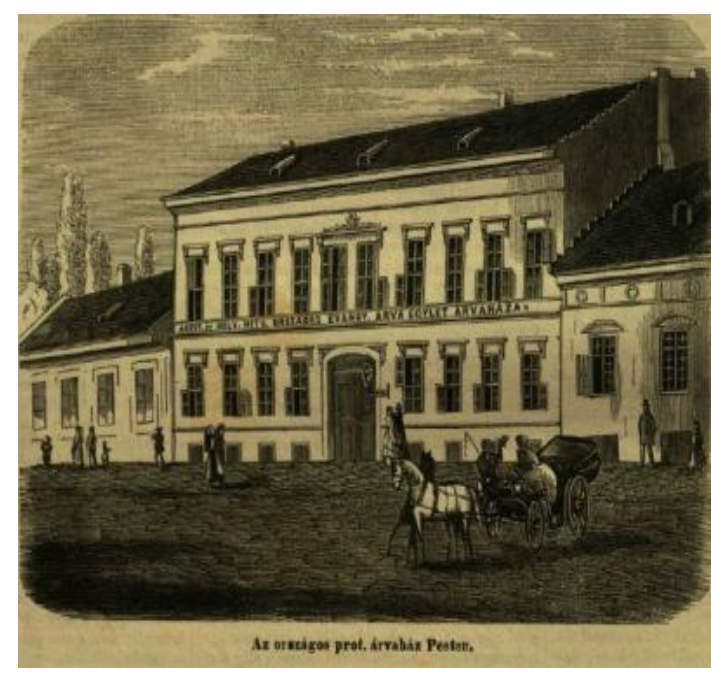
elsősorban öröklési jellegű szerződés (örökössé fogadás), azaz vagyonjogi aktus volt a régi jogfelfogás szerint. Az újkortól az örökbefogadás több funkcióssá vált: nagykorúak örökbefogadása elsősorban öröklési jogi célokat szolgált, életkortól függetlenül a név, a rang stb. továbbvitelének eszközeként jelent meg, de lehetôvé tette a házasságon kívül született gyermek törvényesítését is a házasságról, családról és a gyámságról szóló 1952. évi IV. törvény (a továbbiakban: CSJT) megalkotásáig.

2. kép: Protestáns árvaház (Vasárnapi Újság 1870)

Az örökössé fogadásnak természetesen csak azokban a rétegekben volt értelme, ahol jelentős javakkal rendelkeztek. A nemesi földbirtok - az ősiség értelmében - valójában a családé,

\footnotetext{
${ }^{7}$ MNL, Öröklés http://mek.oszk.hu/02100/02115/html/4-303.html

${ }^{8}$ FÓNAGY, Az örökbefogadás https://orokbe.hu/2014/06/30/az-orokbefogadas-tortenelmi-latoszogbol

${ }^{9}$ BÉLI, Magyar Jogtörténet 62.
} 
nemzetségé volt, nem az egyéné. Ha valaki gyermektelenül halt meg, akkor azt az atyafiság örökölte, a jog által meghatározott rendben - végrendelkezni az örökölt családi birtokról nem lehetett. Az örökbefogadás volt az egyetlen módja, hogy mégis a birtokos személyes akarata érvényesüljön a halál után. A birtokos - a vagyon családban tartása érdekében - leggyakrabban a rokonok közül választott örököst, például valamelyik testvére fiát fogadta örökbe. Mivel az örökössé fogadás célja nem a gyerek felnevelésének biztosítása, illetve valamely érzelmi hiányérzet kielégítése volt, így nem kellett, hogy a gyermek árva vagy elhagyott legyen. Sőt, a jogi aktus következtében nem is feltétlenül került át az örökbe fogadó családjába. A magyar jogrend egészen a CSJT-ig ismerte az adoptio minus plena formulát, azaz a szülői felügyeleti jog átszállása nélküli örökbefogadást.

A fogalom mai tartalmától szintén idegen, hogy a majdani örökösként örökbefogadott akár felnőtt is lehetett. Fiú utód nélküli nagybirtokosok a csak fiágon öröklődő birtokokat vagy a lányuk fiúsításával őrizték meg leszármazottaik számára (királyi engedélyt szereztek lányuk öröklésére), vagy örökbe fogadták a vejüket. A birtokos nemesség esetében nemcsak a rokonság volt ellenérdekelt az örökbefogadással szemben, hanem a királyi kincstár is: törvényes örökös híján ugyanis a birtok arra háramlott volna. Sőt, nem örült az örökös-fogadásnak az egyház sem, mivel a gyermektelenek végrendeletükben gyakran igen bőkezűen hagyatkoztak kegyes célokra. Azoknál a társadalmi rétegeknél, ahol a család, illetve a háztartás a termelőmunka kereteként is szolgált parasztok és iparosok - a gyermeknek munkaerőként is fontos szerepe volt. ${ }^{10} \mathrm{Ez}$ a szempont természetesen érvényesült az örökbefogadással kapcsolatban is. A parasztcsaládok örökbefogadási gyakorlatáról a 19. század végérôl, a 20. század első feléből vannak néprajzi forrásaink. Gyermek hiányában ők is elsősorban a közeli rokonság körében kerestek örökbefogadásra alkalmas fiút.

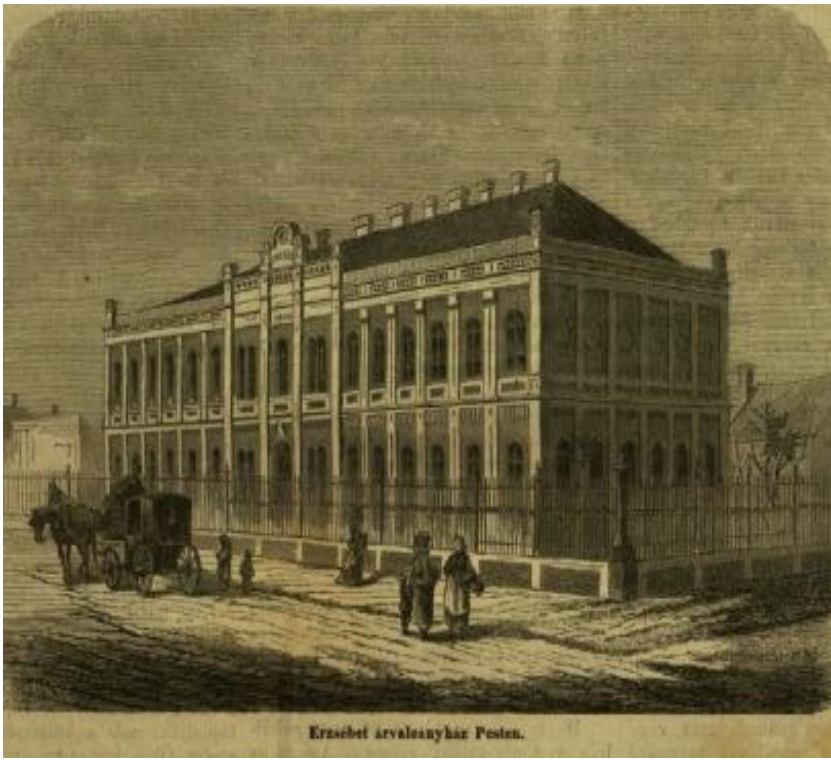

Leggyakrabban többgyermekes testvéreiktől választottak egyet, leginkább a legfiatalabbat. Alkalmas rokongyerek híján számításba jöhetett árva, a századfordulótól - az állami gyermekmenhelyek alapításától kezdve lelencházi gyerek is. Általában egészen fiatal gyermeket hoztak el a menhelyröl, majd ha megszerették, örökbe is fogadták. Voltak jobb módú családok, ahol a munkáskéz biztosítása céljából 2-3 gyereket is örökbe fogadtak.

3. kép: Leány árvaház (Vasárnapi Újság 1872)

Különösen gyakori volt az örökbefogadás a belterjes, munkaerő-igényes gazdálkodást folytató falvakban, például a dél-alföldi dohányosoknál és zöldségkertészeknél. A tanyai gazdálkodásban is előnyt jelentette a családbeli több olcsó munkaerő, amely az örökség vagy

\footnotetext{
${ }^{10}$ Herger, A közszerzemény megosztása 93. és Hegedűs, Családjog 207.
} 
legalább a kiházasítás reményében szorgalmas munkával gyarapította a családi vagyont. ${ }^{11}$ A nagyobb gazdák már az örökbefogadás alkalmával ráírattak a gyerekre valamilyen birtokrészt, a kevésbé tehetősek pedig egy öltözet ruhával vagy kisebb használati tárggyal ajándékozták meg. A nagyobbacska legények esetleg ki is kötötték az örökbefogadás feltételéül, hogy előzőleg földet írassanak rájuk, nehogy hiába essen a munkájuk. A 20. század elejétől a paraszti világban a tehetős gazdáknál akkor is előfordult örökbefogadás, ha voltak gyermekeik. Ilyenkor az örökbefogadott „nem egész örökös” volt, azaz nem számíthatott egyenlő örökösödésre. Öt munkája fejében fölnevelték, kiházasították és az induláshoz adtak neki valamit a vagyonból is. A parasztság körében csak a teljes jogú örökbefogadást ismerték, azaz a gyermek bekerült a családba, új apja, akinek a nevét, sőt még a ragadványnevét is viselte, a teljes atyai hatalmat gyakorolta felette. Helyzete a családon belül ugyanaz volt, mint a vér szerinti gyermeké. Neve sokfelé „örökös gyerek” volt, ami utalt az örökbefogadás régebbi tartalmára. ${ }^{12}$

Az örökbefogadás jogi aktusának a tradicionális jogban nem volt egységes és általános szabályozása, ezen a téren is a „kinek-kinek a magáét’ elv érvényesült. Azaz a rendi állás számított: a nemes a vármegyén, illetve a kormányszerveken keresztül a királytól szerzett megerősítést szándékára, a jobbágy a földesúrtól, a polgár pedig a városi magisztrátustól. ${ }^{13}$

\section{Az örökbefogadás az osztrák természetjogi kódexben}

Az örökbefogadás intézménye a német jogkörben későn, római jogi hatásként jelent meg. Ahogy a magánjogi intézmények többsége, úgy az örökbefogadás is a római jogban jelent meg először, mint jogilag szabályozott aktus. Ennek az intézménynek a segítségével már a kezdetektől fogva a természetes utódok hiányát kívánták pótolni, vigaszt nyújtott az elvesztett gyermekekért ${ }^{14}$, de egyúttal az örökhagyó még életében gondoskodhatott arról, hogy legyen, aki tovább vigye a nevét, vallási és egyéb kötelességeit, gondoskodjon a fennmaradó családtagjairól amellett, hogy vagyonát örökölje, s ez utóbbi volt az elsődleges célja, mégis családjogi intézményként jelent meg. ${ }^{15}$

A germán népek jogéletében a római jogi manus intézményével rokonítható Munt különböző formái voltak ismertek (férj Muntja felesége felett, a családfő Muntja gyermekei felett és a családi házközösséghez tartozó más személyek, így rokonok és házi szolgák felett), és így az árva feletti gyámi Munt, amelynél fogva örökbefogadásra nem volt szükség, mivel a nemzetség legidősebb férfitagjának gyámi hatalma pótolta azt. Ilyen módon a német jogfejlődésben a gyámság intézménye bizonyos értelemben az örökbefogadás előzményének is tekinthető. A germán jog megkülönböztette az ún. szerződési rendszert (Vertragsystem) az ún. rendelet rendszertől (Dekretsystem). Előbbi azt jelentette, hogy az örökbefogadó és a gyermek között kötött szerződéses jogviszony által jön létre az örökbefogadás, míg a rendeleti rendszer szerint szuverén állami aktus (Hoheitsaket) hozza létre a jogintézményt. Jelentős különbség a kettő között, hogy az örökbefogadó rokonságágára is kihat-e az örökbefogadás (Volladoption) annak minden joghatásával vagy csupán

\footnotetext{
${ }^{11}$ MNL, Öröklés http://mek.oszk.hu/02100/02115/html/4-303.html

12 MNL, Öröklés http://mek.oszk.hu/02100/02115/html/4-303.html

${ }^{13}$ FÓNAGY, Az örökbefogadás https:// orokbe.hu/2014/06/30/az-orokbefogadas-tortenelmi-latoszogbol

${ }^{14}$ WEISS, Az örökbefogadás néhány társadalmi és jogi kérdése 180.

15 BEKE-MARTOS, Az örökbefogadás - jogtörténeti megközelítésben 18.
} 
az örökbefogadó és az örökbefogadott gyermek között keletkeztet jogokat és állapít meg kötelezettségeket (Teilwirkungen). ${ }^{16}$

A természetjogi kódexek közé sorolt, 1811-ben elfogadott OPTK már ismerte az örökbefogadás intézményét. Szabályozása nem csak azért érdekes, mert megmutatja, milyen tartalmat hordozott ez a gyerekcipőben járó intézmény az osztrák örökös tartományokban, hanem azért is, mert 1853-ban hatályba lépett Magyarországon, valamint Horvátországban, Szlavóniában, a Szerb Vajdaságban, a Temesi Bánságban és Erdélyben is. Korszerú magyar rendelkezések hiányában nagy szükség volt az osztrák kódex szabályaira az örökbefogadással kapcsolatos jogvitákban. Sôt, bár az Ideiglenes Törvénykezési Szabályok 1861-ben a tradicionális magyar magánjog jelentős részét helyreállították a neoabszolutizmus erőszakos jogexportja után, az osztrák kódex rendelkezései az örökbefogadás esetében az 1877. évi XX. törvénycikk (ún. Gyámtörvény) megalkotásáig hatályban maradtak. ${ }^{17}$

Az OPTK-t 1870-ben másodszor is kiadták Pesten hivatalos magyar nyelvű fordításban, amit ugyan az is indokolt, hogy 1861-ben csak részleges lehetett a visszatérés a magyar tradicionális magánjoghoz, de elsősorban arról volt szó, hogy a magyar Korona mellékországaiban az OPTK továbbra is hatályban volt és ezért a királyi Curia a magyar és az osztrák jogot párhuzamosan alkalmazta az elé került ügyekben. A fent említett kiadás fordítását idézve az OPTK III. fejezete (A szülék és gyermekeik közötti jogokról, azonbelül a szülék és gyermekeik közti jogviszonyhoz hasonló összeköttetések címszó) foglalkozik az örökbefogadás jogintézményével mindössze 7 \-on keresztül. A törvénykönyv szerint „azok, kik házasságtalanságot ünnepébyesen nem fogadtak, ha törvényes saját gyermekeik nincsenek, gyermekeket örökbe felvehetnek: a felvevö személy fogadó-atyának vagy anyának, a felvett pedig fogadott gyermeknek neveatetik" (179. §). ${ }^{18}$ Az örökbefogadó személyét illetően a törvény mindössze egy feltételt támasztott, mégpedig az életkor tekintetében: az ötvenedik életév betöltése, egyszersmind az örökbefogadott gyermeknél legalább 18 évvel idősebb személy (180. J). A törvénykönyv mind a kiskorú, mind a teljeskorú gyermek örökbefogadását lehetővé tette, aszerint differenciált, hogy kinek a beleegyezése szükséges az örökbefogadáshoz. Teljeskorú fogadott gyermek esetén az atyja beleegyezése megkívántatott, kiskorú gyermek örökbefelvételénél elsősorban az atya, ha az atya nem élt, akkor az anya, a gyám, a bíróság belegyezésére volt szükség. Amennyiben az atya elegendő ok nélkül tagadta meg az örökbefogadást, a törvény jogorvoslatként panasztételt engedett a rendes bírónál. Az örökbefelvételt be kellett jelenteni, mely egyrészről a kormányszék által végzett megerősítés, másrészről pedig a bírósági nyilvántartás miatt volt kiemelten fontos (181. §).

A törvény az örökbefogadás joghatásai közül a névviselést és a családi kapcsolatot szabályozta. A fogadott gyermek vagy a fogadó-atya nevét vagy a fogadó-anya nemzetségi nevét, de egyszersmind a fogadó-atya családi nevét, és az ôt illető családi nemességet is megtartja (182. §). Nemesség, címer átszállásához a fejedelem engedelmére volt szükség. A családi kapcsolatot illetôen a fogadott gyermek és utódai a fogadó atya atyai hatalma alá kerültek, ugyanazon jogállás illette meg

\footnotetext{
16 SCHWAB, Familenrecht 300.

17 VÉKÁs, Az osztrák Polgári Törvénykönyv 22-28.

18 Örökbe-fogadott: Kit valaki saját gyermeke gyanánt fogad, nevel, és javainak örökösévé tesz. Örökbefogadott árva. Lásd: CZUCZOR - FOGARASI, A magyar nyelv szótára http://mek.oszk.hu/05800/05887/cimkes.html
} 
őket, mint a saját gyermekeket, ugyanakkor az örökbefogadás nem terjedt ki az örökbefogadó szülők családjának többi tagjaira, csupán a fogadó atya, anya és a fogadott gyermek viszonylatában hozott létre családi jogállást, létesített jogokat és kötelezettségeket, amely jogviszonyban a fogadott gyermek nem vesztette el önnön családja jogait (183. §). A kódex által szabályozott - fogadott gyermek és fogadó szülék közötti jogoktól - a felek szerződésben eltérhettek, ha mások jogai nem rövidültek, valamint ha a szerződés lényeges változást nem tartalmazott az említettekhez képest (184. §). A fogadó szülék és a fogadott gyermek közötti kötelezettségeket a törvény nem említette, nem szabályozta. Elenyésztők címszó alatt a felbontható örökbefogadás mellett foglalt állást, mely védte a kiskorú gyermek érdekeit, annak fennállása esetén csak a gyermek képviselói és a bíróság beleegyezésével volt megszüntethető. Amennyiben az örökbefelvétel, mint jogviszony elenyészett, a gyermek ismételelten törvényes atyja hatalma alá került vissza (185. §). Az örökbefogadás jogai és kötelezettségei olyan gyermekre nem vonatkozhatott, akik egyedül tápolás végett véttettek fel. Ez a tápolás mindenki szabadságában állt, ha azonban a felek eziránt szerződésre akartak lépni, akkor a tápgyermek jogait megszorították, rá „,különös köteleztetések” vonatkoztak, melyet bíróság előtt meg kellett erősíteni. A tápolás költségeit a tápszülék nem követelhették (186. §).

\section{Az örökbefogadás szabályozása Magyarországon}

Az örökbefogadás célja, rendeltetése a magyar jogfejlődésben is hosszabb időn át elsődlegesen az öröklés volt. Az örökbefogadás magyar kifejezése az „örökségbe” fogadást, azaz az örökössé tételt jelentette. ${ }^{19} \mathrm{~A}$ tradicionális magyar magánjog ismerte az adoptio filialis intézményét. Örökbefogadás által az szerzett nemességet, akit a magvaszakadt ${ }^{20}$ nemes királyi hozzájárulással fiává fogadott és ezzel adományos birtokaiban örökösévé tett. Az örökbefogadás érvényességi feltételei a fiúsításéval (praefectio) ${ }^{21}$ egyeztek meg. A fiúsítás azt jelentette, hogy a fiágon magvaszakadt nemes leányát vagy nőrokonát a férfiakat illető öröklési joggal ruházta fel a király. A fiúsítás lehetősége miatt a magyar nemesi jogéletben az örökbefogadás intézményére korlátozottan volt csak szükség.

A magyar jogfejlődés jellegzetessége, hogy az örökbefogadást már a Tripartitum is tartalmazta, és megengedett volt a kiskorúak és a nagykorúak örökbefogadása (a germán joghoz hasonlóan) az öröklés céljával: Werböcryy István először 1517-ben Bécsben kiadott jogkönyve, mely a teljes magyar jog (szokások és törvények) feljegyzése volt, a nemesség magánjogi viszonyai kapcsán szabályozta az örökbefogadás intézményét, rendelkezett a testvérré fogadásról is. A Tripartitum az örökbefogadást elsősorban a nemessé válás egyik lehetséges módjaként tárgyalta. Ha ugyanis nemes nem nemest fogadott örökbe, azt a majdan megöröklendő birtok nemessé tette. Igaz, ehhez királyi megerősítést is kellett szerezni, ugyanúgy, mint ha a család főnemesi (grófi, bárói) címét akarták megmenteni. „Továbbá még más módon is lehet valaki nemessé; örökkbe fogadás útján: a mikor

\footnotetext{
${ }^{19}$ KATONÁNÉ PeHR, Az örökbefogadás 37. Örökbefogadás: Cselekvés, midőn valakinek természetes örököse nem lévén, idegent veszen föl saját gyermekéül és örököséül. Lásd: CZUCZOR - FOGARASI, A magyar nyelv szótára http://mek.oszk.hu/05800/05887/cimkes.html

${ }^{20}$ Magvaszakadt: Mondjuk emberről, kinek gyermeke, s örököse nincsen, kiben a nemzetség vagy család kihal. Innen magvaszakadt jószág am. örökös nélküli, rendszerént az állodalomra szálló jószág. Lásd: CZUCZOR - FOGARASI, A magyar nyelv szótára http://mek.oszk.hu/05800/05887/cimkes.html

${ }^{21}$ Fiúsítás: A magyar törvényben am. a leányt fiúi jogokkal felruházza, a fiút illető örökséget reá hagyja. Lásd: CZUCZOR - FOGARASI, A magyar nyelv szótára http://mek.oszk.hu/05800/05887/cimkes.html
} 
tudniillik valamelyik úr vagy nemes valamely parasztot vagy nem nemest fiaként örökbe fogad és fekvoó jószágainak utódjává és örökësévé rendel; ha az ilyen örökbe fogadáshoz a királyi jóvábagyás járul és ezt a jószágaiba való törvényes beiktatás is követi (mivel a₹ örökbefogadásnak épen úgy, mint a fiusitásnak királyi jóvábagyás mellett adományereje van) az a nem nemes és ennek. fiai igazi nemesek számába jönek”" (8. cím). „Készakarva mondám pedig: örökeösök hiányában, mert ha valóságos és törvényes örökösök és utódok létęnek és maradnak hátra, a testvérré fogadásnak helye nincsen; de ezeknek biányában ama fekvoó jószágok háramlására nézve, az. ilyen utódlás batalmára és jogára a testvérré vagy fiúvá fogadott fog sžert tenni” (66. cím 3. \$). „Mivel a gyámság átszállása, mint már elóbb mondám, a fekvoó jószágok háramlása sz̧erint történik, ažért, ha valakinek fiágban magvaszakad és leányai vannak, a gyámság viselése azokera azörökebe fogadott atyafiakra is, mint fiági rokonokera jogosan átszáll és átmegy, a kikere valamely szerzôdés vagy királyi jóváhagyás erejénél fogva a magvaszakadtnak fekvoó jószágai és birtokjogai háramlanak, a minek bármely leányágai rokon joga és gyámsága útját nem állja (120. cím 1.\$). (Például a 20. század elején a gyermektelen utolsó Benyous₹łky gróf, Sándor a család nemesi ágából fogadott örökbe két fiút, akik ekkor már 28, illetve 30 évesek voltak.) ${ }^{22}$

Az OPTK magyarországi hatályba léptetése témánk szempontjából azt jelentette, hogy az örökbefogadás természetjogi szemlélettel és törvényi jogi szabályozással lett a magyar magánjog része mindaddig, míg (hasonló szabálytartalommal) saját magyar törvény nem született ebben a tárgyban 1877-ben.

A gyámsági és gondnoksági ügyek rendezéséről szóló 1877. évi XX. törvénycikk anyagi jogi és eljárásjogi rendelkezéseket is tartalmazott. A törvény szerint a gyámhatóság legfőbb feladata a gyámoltak és gondnokoltak szellemi és anyagi érdekeinek az előmozdítása, valamint a megóvása volt. Rendkívül sokrétű feladatot első fokon a törvényhatóságok és a rendezett tanácsú városok, kivételképpen pedig a községek árvaszékei látták el.23 A törvény abból az aspektusból indult ki, hogy a gyámügyekben a községnek, valamint a családnak is kellő befolyást kell biztosítani, így szakítani kíván a 16. századbeli irányzattal, mégpedig: amely szerint az állam intézi, kezeli és igazgatja a gyámügyeket a család és a község kizárásával, a gyámot a gyámhatóság mechanikus közegének tekintve. Így tehát be kell vonni a családot és a községeket a gyámhatósági munkába. A törvénycikk két részből állt: az első rész a gyámságról és a gondnokságról, valamint az ehhez kapcsolódó jogintézmények szabályozásáról, a második rész pedig a gyámhatóságokról és a hozzá kapcsolódó jogintézmények szabályozásáról szól. A törvény megállapította, hogy a kiskorú cselekvőképessége a 12. életév betöltésével kezdődik, a teljes nagykorúság határát pedig a 24. életévben jelölte meg. Általános elvként szögezte le a törvény, hogy a kiskorúak gyámság vagy atyai hatalom alatt állnak, valamint az atyai hatalom és gyámság egymást kizáró jogintézmények, így együtt meg nem állhatnak. ${ }^{24}$

A törvény a gyámságra hivatott személyek sorrendjét is megállapította. A gyámok tekintetében a római jogi eredetű csoportosítást használta, amelyet már a régi jogunk is követett. Így tehát megkülönböztetünk nevezett, természetes és törvényes (törvényes és rendelt) gyámot. Amennyiben az elhalt atya nem nevezett meg gyámot, úgy a gyám tisztsége az anyára, mint természetes és törvényes gyámra szállt, abban az esetben viszont, ha az atya nevezett gyámot, akkor

\footnotetext{
22 FÓNAGY, Az örökbefogadás https:/ / orokbe.hu/2014/06/30/az-orokbefogadas-tortenelmi-latoszogbol

23 ZÁmBÓ, A gyámhatóságok 1. Lásd továbbá: Árvaszék: Árvák ügyeire vonatkozó tanácskozmány vagy tárgyalás; árvabiróság. Lásd: CZUCZOR - FOGARASI, A magyar nyelv szótára http://mek.oszk.hu/05800/05887/cimkes.html ${ }^{24}$ SISKA, Az árvaszékek története és jogi szabályozása 118-119.
} 
a gyámi tisztség a nevezett személyt illette meg, az anya pedig csak azt követelhette, hogy a kiskorú gyermekeit magánál tarthassa és azok személyi, valamint vagyoni ügyeiben őt meghallgassák.

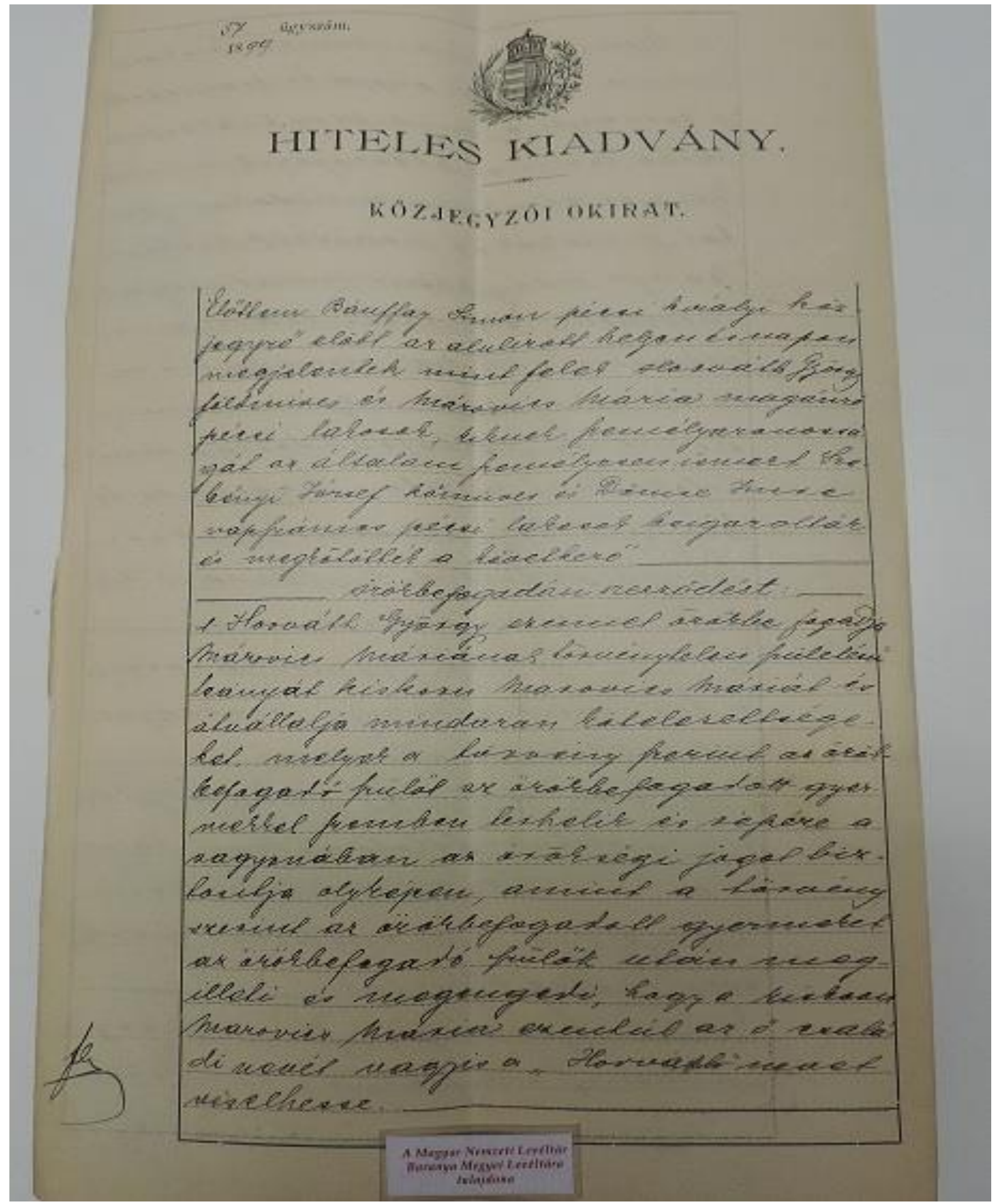

4. kép: Törvénytelen gyermek örökbefogadásáról rendelkező örökbefogadási szerződés MNL BML IV. 1409.b. II-891899 
A törvénycikk 43. \-a kizárta a nőket a gondnokság és a gyámság viseléséből. Az árvaszékek törvényi szabályozását követően az 1877. évi 47046. számú rendeletével a belügyminiszter szabályozta az árvaszékek ügyrendjét. Ezzel befejeződött az árvaszékek egységes központi szabályozásának menete. ${ }^{25}$

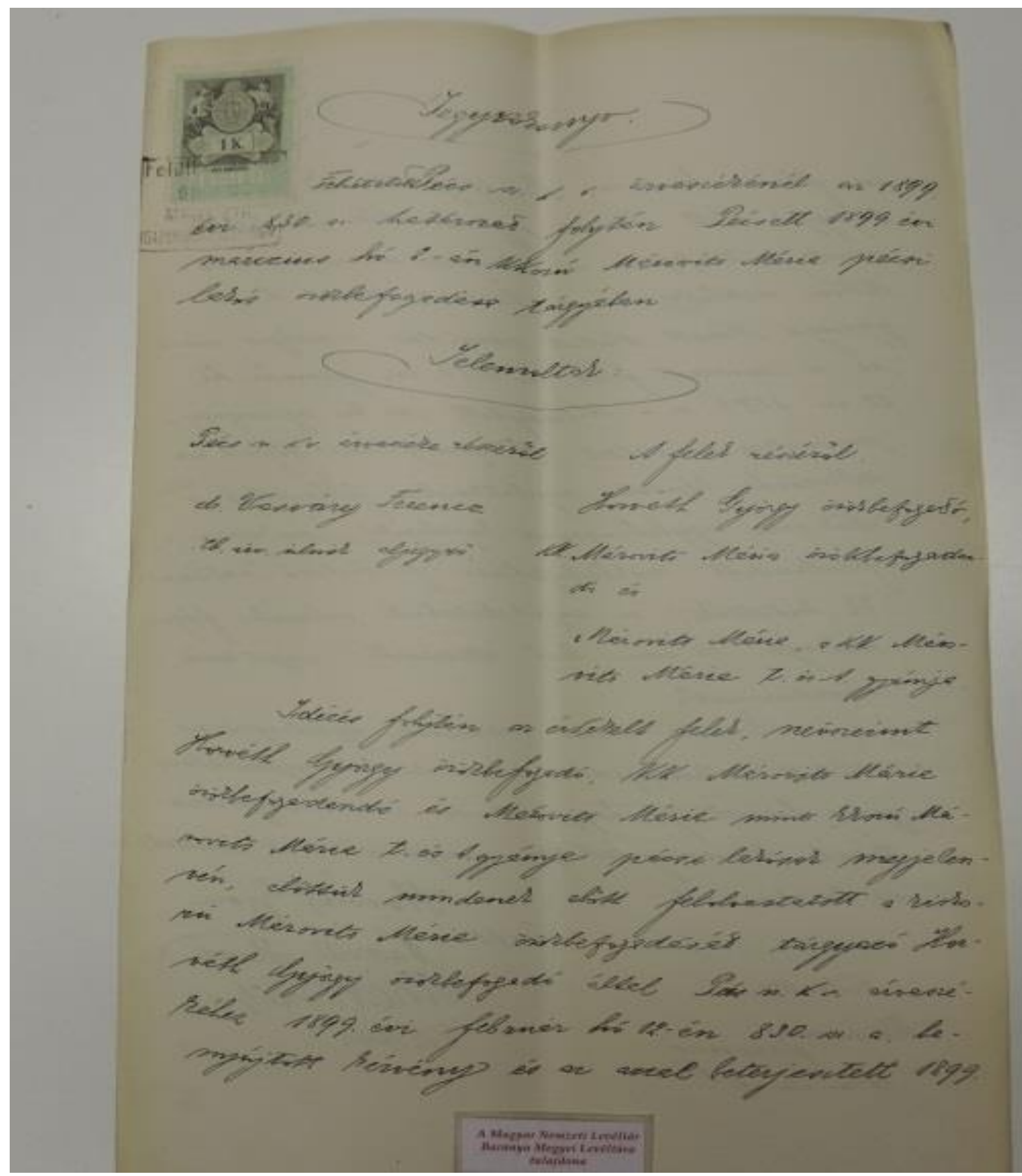

5. kép: Pécsi lakosú kiskorú gyermek örökbefogadása tárgyában készült jegyzőkönyv MNL BML IV. 1409.b. II-891899

${ }^{25}$ SISKA, Az árvaszékek története és jogi szabályozása 124-128. 


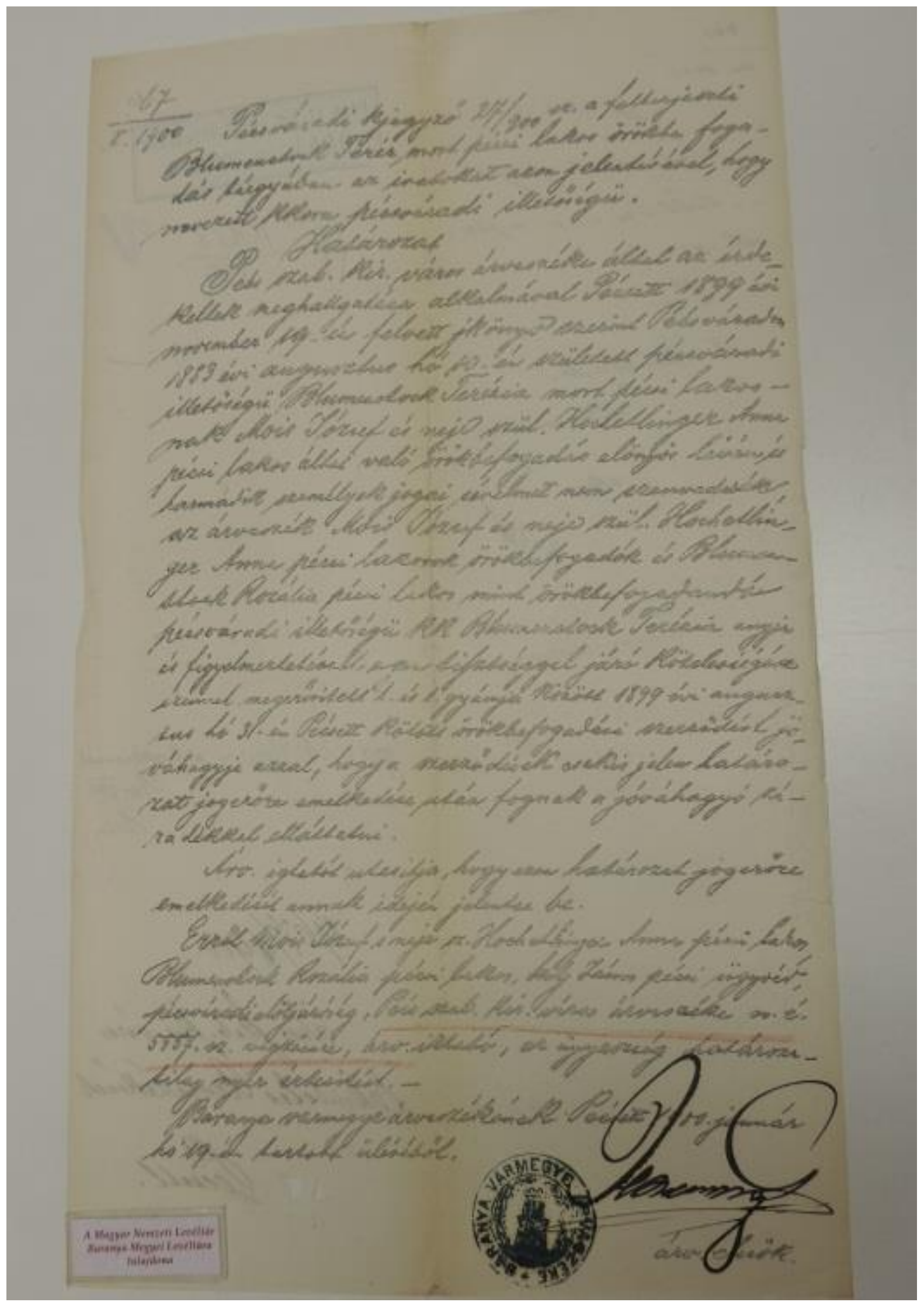

6. kép: Baranya Megye Árvaszékének határozata az örökbefogadás jóváhagyásáról MNL BML IV. 1904.b II-1008-1899 
Márkus Dęsṓ tanítványa, Meszlény Artúr egyetemi tanár, ügyvéd által írt, 1931-ben megjelent Magyar magánjog I. c. mű szükségessége abból következett, hogy a magánjogi kodifikáció hazánkban sikertelen volt. A magánjogi kódex 1900. évi I. tervezetét ugyan további négy követte a századforduló utáni első két évtizedben, melyeket nagy szakmai igényességgel dolgoztak ki, az Országgyúlés elé terjesztett $\mathrm{V}$. tervezet elfogadása 1928-ban elmaradt. Mes₹lény három évvel később úgy egészítette ki Márkus Dęső́ századforduló éveiben kiadott Magyar magánjog c. mûvét, hogy annak alapját az MTJ képezte: a javaslatból idézett szakaszok tartalmát mutatta be a magyar jogfejlődés egészére nézve. Ezáltal pontos képet adott arról, hogy hogyan alakult az adott szokásjogi jogintézmény a bírói jogban és arra tekintettel a kodifikátorok milyen álláspontot alakítottak ki. Közvetett hatása ennek a módszernek az volt, hogy segítette a törvényként el nem fogadott ún. kodifikálatlan kódex tartalmának a mindennapi jogéletbe való átvételét.

Az MTJ az örökbefogadás intézményét az OPTK-hoz képest lényegesen részletesebben szabályozta. Az örökbefogadás érvényes létrejötte feltételeként nem kívánta meg, hogy a leendő fogadó szülő házasságtalanságot fogadjon, csupán annak a három feltételnek kellett teljesülnie, hogy nagykorú legyen, ne legyen ivadéka, és legalább tizenhat év korkülönbség álljon fenn az örökbefogadó szülők és örökbefogadott között. A törvénykönyv magyarázata szerint ivadék alatt a lemenő rokont kellett érteni (175. §), nagykorú személy pedig az volt, aki a 24. életévét betöltötte (16. §) Kivételt képezett e szabály alól, a különös méltánylást érdemlő eset, melynek fennállása esetén az igazságügyminiszter megerősíthette az örökbefogadó szerződést akkor is, ha az örökbefogadónak vérszerinti ivadéka volt vagy a korkülönbség kelléke hiányzott, de legalább tizenkét évvel idősebb volt az örökbefogadó szülő az örökbefogadottnál (207. \$). A hazai jog nem kívánta meg azt, hogy az örökbefogadó legalább ötvenéves legyen, ez a követelmény csak azon örökbefogadók tekintetében állt fenn, akik a haza azon területén éltek, ahol az osztrák polgári törvénykönyvet ideiglenesen hatályban tartották. A törvény nagykorú örökbefogadását is megengedte. Nagyszülő örökbe fogadhatta unokáját, ugyanazon örökbefogadó a szülőt és annak gyermekét is ${ }^{26}$, a gyám gyámoltját, izraelita vallású egyén a keresztény vallású kiskorú egyént ${ }^{27}$, de a gondnokság alatt álló személyeket is örökbe lehetett fogadni ${ }^{28}$, ahogy nemes ember parasztot is örökbe fogadhatott. ${ }^{29}$ Törvényesített, saját gyermek örökbefogadását a törvény expressis verbis kizárta, azonban lehetôvé tette, hogy a természetes atya saját törvénytelen (utóházassággal nem törvényesített) gyermekét örökbe fogadja (704. \). ${ }^{30}$ A törvény tilalmakat is felsorolt, mégpedig a testvérek közötti örökbefogadást ${ }^{31}$, a magzat (nasciturus) örökbefogadását ${ }^{32}$, a házastársnak saját házastársa, vagy házastársa elődjének örökbefogadását. Előd alatt a felmenő rokont kellett érteni (175. S). Az MTJ kimondta, hogy hazai jogunkban nem létezik szabály, mely Magyarországnak az osztrák polgári törvénykönyv uralma alatt álló részein kívül lakó egyéneknek, ha törvényes leszármazóik vannak, az örökbefogadást megtiltaná (207. \). Több örökbefogadó ugyanazt a személyt nem fogadhatta örökbe, a házastársak kivételével. Az örökbefogadás fennállása alatt az

\footnotetext{
${ }^{26}$ MESZLÉNY, Magyar Magánjog I. 694.

27 MESZLÉnY, Magyar Magánjog I. 695.

28 MESZLÉnY, Magyar Magánjog I. 698.

${ }^{29}$ MeszLÉnY, Magyar Magánjog I. 704.

30 MeSZLÉNY, Magyar Magánjog I. 711. valamint 19405/1887 I.M. sz.

31 Meszlény, Magyar Magánjog I. 695.

32 MESZlénY, Magyar Magánjog I. 698.
} 
örökbefogadott gyermeket csak az örökbefogadó házastársa fogadhatta örökbe. Az örökbefogadó halála után az igazságügyminiszter különös méltánylást érdemlő esetben ezen tilalom alól kivételt tehetett $^{33}$ (208. §). A házastárs csak a másik házastárs beleegyezésével fogadhatott és volt örökbe fogadható, kivéve, ha ágytól és asztaltól el voltak választva. ${ }^{34}$ A törvény ez alól is kivételt tett, kimondta, hogy az egyik házastárs jogosítva van egyedül, házastársa beleegyezése nélkül is örökbe fogadni. ${ }^{35}$ Közös gyermekké fogadásnak nevezi a törvény, ha az egyik házastárs a másik házastárs gyermekét fogadja örökbe, kivéve, ha a feleség fogadja örökbe férjének házasságon kívüli gyermekét (208. §).36A Magyar Nemzeti Levéltár Baranya Megyei Levéltárában 1872-1910 között megtalálható iratanyagok többsége házastársi örökbefogadásról szól, mind a feleség, mind a férj oldaláról nagyszámban fordult elő olyan örökbefogadás, amikor a házastársa házasságon kívül született (törvénytelen) gyermekét fogadta örökbe.

A törvény részletesen szabályozta, hogy mely személyek beleegyezésére volt szükség az örökbefogadáshoz (209. §). Kiskorú törvényes gyermeket csak szülőinek, kiskorú házasságon kívüli gyermeket csak az anyja beleegyezésével fogadhatták örökbe. A beleegyezést közhatóság előtt kellett jegyzőkönyvbe mondani, vagy közokiratban kijelenteni, mely beleegyezés nem volt visszavonható. Annak a személynek a beleegyezését, aki távol volt, cselekvőképtelen vagy a nyilatkozat megtételében tartósan gátolva volt, mellőzték. ${ }^{37} \mathrm{~A}$ felek örökbefogadás iránti szándékát - valamint, ha az örökbefogadandó gyermek a 14. életévét betöltötte az ő véleményét - az eljáró árvaszék vagy a lakóhelyükhöz legközelebb eső szolgabíróság vette jegyzőkönyvbe.

Az atyai hatalmat gyakorló atya vagy a gyám kérelmezhette az örökbefogadás gyámhatósági jóváhagyását, az erre vonatkozó kérelemhez csatolni kellett az örökbefogadó és az örökbefogadott keresztelő vagy születési bizonyítványát; amennyiben a gyermek törvénytelen származású volt, akkor az édesanyjának a születési vagy keresztelő bizonyítványát is; ha az örökbefogadók házastársak voltak, akkor a házassági bizonyítványukat; amennyiben a törvényes atya, vagy a törvénytelen születésű örökbefogadandónak anyja vagy a szülők egyike sem élt, akkor a halotti bizonyítványokat, valamint a gyám által képviselteknél a gyámi rendelvényt. A kérvény felett az árvaszék, mint gyámhatóság döntött. Amennyiben az örökbefogadást a kiskorú érdekében állónak tartotta határozatában jóváhagyta, jogerő után záradékolta, a szerződés három példányát felterjesztette az igazságügyminiszterhez végső elhatározás végett. ${ }^{38}$

Levéltári kutatásaim alapján az örökbefogadási szerződések többsége azzal indokolta a gyermek érdekében álló örökbefogadást, hogy annak létrejöttével a gyermek családi jogállása rendeződik (tehát törvénytelen származása megszűnik), örökösödési jogot (beleértve a kötelesrészt is), atyai hatalmat kap és jogosult viselni az örökbefogadó családnevét. Az áttekintett levéltári iratok mindegyike az örökbefogadott gyermeket saját családi nevének elhagyásával az örökbefogadó családnevének viselésére kötelezte.

\footnotetext{
33 MeSZLÉNY, Magyar Magánjog I. 696.

34 MESZLÉNY, Magyar Magánjog I. 697.

35 MesZlénY, Magyar Magánjog I. 697.

36 MESZLÉNY, Magyar Magánjog I. 703.

37 MESZlÉNY, Magyar Magánjog I. 697.

38 MesZLÉNY, Magyar Magánjog I. 699-700.
} 
Aktív örökbefogadási képessége a teljeskorú és önrendelkezési joggal bíró magyar állampolgárnak volt (208. §).39 A vallási hovatartozás az örökbefogadási képességet nem befolyásolta: görög-katolikus, görög-keleti, protestáns, izraelita rabbi is örökbe fogadhat, kivéve a római katolikus lelkész és az ünnepélyes fogadalmat tett lelkészek. Aki házasságot egyházi rend vagy fogadalom okán nem köthetett, az a személy csak egyházi felsőbbség engedelmével fogadhatott örökbe (210. §).40

Az örökbefogadó szerződést az örökbefogadónak magával az örökbefogadandóval kellett megkötnie.41 Az örökbefogadás iránt szerződő nagykorú felek gondoskodtak a szerződés anyagi és alaki szabályszerűségéről. Amennyiben az örökbefogadandó tizenkettedik életévét nem töltötte be, a szerződést a gyámhatóság jóváhagyásával a kiskorú törvényes képviselője kötötte meg az örökbefogadóval. ${ }^{42}$ A kiskorú törvényes képviselője elsősorban az atyai hatalmat gyakorló atyja volt, ha az atya nem élt, vagy az örökbefogadott törvénytelen születésú volt akkor az anya, ha az atyai hatalom gyakorlata felfüggesztetett vagy egyik szülő sem élt, akkor az árvaszékileg kirendelt gyám következett a sorban, aki megköthette az örökbefogadó szerződést (211. 』).43 E szerződést három eredeti példányban közokiratba kellett foglalni, kivéve, ha királyi közjegyző előtt köttetett, mert akkor három hiteles kiadványa készültt. ${ }^{44} \mathrm{~A}$ szerződő felek szegény sorsára tekintettel a törvény kivételt engedett az írásbeliség alól, mert az árvaszék előadója vagy az árvaszék által megbízott szolgabíró előtt szóban is megköthető volt. Levéltári kutatásaim bizonyítják, hogy gyakran éltek ezzel a lehetőséggel a szegény körülmények között élő családok, akik szegénységi bizonyítvánnyal igazolták állitásukat és kérték, hogy a szükséges okmányokat az árvaszék szerezze be. ${ }^{45}$

Az örökbefogadási szerződésbe belefoglalták mindazon jogokat (öröklési jog, névátruházás stb.) amelyek az örökbefogadó az örökbefogadottra és utóbbinak törvényes képviselője az örökbefogadóra (atyai hatalom, gyámság) átruházott. Az örökbefogadás joghatásait illetően a törvény a névátruházást szabályozta elsőként, mely szerint az örökbefogadó családi vagy az örökbefogadó nő születési családneve ruházható át az örökbefogadottra. ${ }^{46}$ Közös gyermekké fogadás esetén a férj családi neve átruházható volt, kivéve, ha az igazságügyminiszter a közrend érdekével ellentétesnek vélte és megtagadta. A felek megállapodhattak abban, hogy az örökbefogadott az átruházott családi nevéhez saját családi nevét kapcsolja, vagy utóbbit elhagyja. Amennyiben ilyen megállapodás nem született, akkor a családi nevet saját családi nevének elhagyásával köteles volt viselni. Ha az örökbefogadó nem ruházta át saját családi nevét és erről a szerződés sem rendelkezett, akkor az örökbefogadott neve az örökbefogadás folytán nem változott. ${ }^{47} \mathrm{Ha}$ a saját családi nevéről az örökbefogadott nem nyilatkozott, akkor nem kötelezte magát arra, hogy saját családi nevét elhagyja (216. §).48 Kivétel nélkül minden levéltári örökbefogadási szerződés rendelkezik arról, hogy az örökbefogadott addig viselt családnevét hagyja

\footnotetext{
${ }^{39}$ MEsZlÉnY, Magyar Magánjog I. 697.

40 MeszlénY, Magyar Magánjog I. 700.

${ }^{41}$ MeSZlénY, Magyar Magánjog I. 700.

42 MeszlénY, Magyar Magánjog I. 700.

43 MeszlénY, Magyar Magánjog I. 698.

${ }^{44}$ MeSZLÉNY, Magyar Magánjog I. 699.

45 MNL BML IV. 1409.b. 687-1905

46 MESZlénY, Magyar Magánjog I. 699.

47 MESZlÉNY, Magyar Magánjog I. 706.

48 MESZlénY, Magyar Magánjog I. 707.
} 
el és viselje az örökbefogadó atya családnevét, melyről a magyar királyi igazságügyminisztérium kormányhatósági megerősítésében (utolsó bekezdés) is rendelkezett.

Magyar nemesség (nemesi, főnemesi cím, előnév, címer) átruházásával kapcsolatos örökbefogadási ügyletet nem lehetett létesíteni. Az örökbefogadott gyermek tartásra volt jogosult (rendes bíróság hatáskörébe tartozott), vérségi összeköttetésen alapuló minden joga fennmaradt (öröklés, tartás és nevelés iránti igénye), mivel az örökbefogadás nem szüntette meg a vérségi kapcsolatot és az ezen alapuló öröklési jogot. ${ }^{49} \mathrm{Az}$ örökbefogadó szerződésben az örökbefogadott kiskorú vérszerinti apja és törvényes képviselője nem mondhatott le mindazon kötelezettségekről, amelyek ôt mint apát terhelték, mert a természetes szülőnek a más által örökbefogadott gyermeke iránti kötelezettségei az örökbefogadás ténye dacára is fennmaradtak. Az örökbefogadás következtében azonban megszűnt az örökbefogadott vérszerinti szülőinek szülői hatalma. Ha az örökbefogadott kiskorú volt, akkor fennmaradt a vérszerinti szülő személyes érintkezési joga, melyet szerződésben is szabályozhattak (219. §).

Az örökbefogadó halála után az örökbefogadott gyermek egyenlő jogi szempont alá esett az örökbefogadó leszármazóival. Az örökbefogadott gyermeket a törvényes gyermekhez hasonló osztályrész illette meg az örökbefogadó szülők után, az özvegyi jog korlátozását is kérhették. Az örökbefogadott után az örökbefogadó nem örökölhetett, tehát az örökbefogadás folytán az örökbefogadó szülők után egyoldalú jog keletkezett az örökbefogadott javára (217. §). Az örökbefogadott törvényes örökösödési jogát kitagadás útján vonhatták el, ha a vérszerinti szülők az örökségből kitagadták. ${ }^{50}$ Tehát az örökbefogadott gyermeknek - a PTK 1977. évi módosításáig - kettős öröklési joga volt: vérszerinti rokonai, valamint örökbefogadói és azok rokonai után úgy, mint az örökbefogadók vérszerinti gyermeke. Ez a kettős öröklési jog azt jelentette, hogy a vérszerinti szülők hagyatéki tárgyalása során fel kellett tárni, mi az örökbefogadott eredeti (örökbefogadás előtti) neve, hol él, kiknek a gondozásában van. A vérszerinti rokonok így megismerték, hova került a gyermek és nagyon sok esetben zaklatták az örökbefogadókat, de magát a gyermeket is megkísérelték elidegeníteni örökbefogadóitól. Ezen a helyzeten lényegében segített a PTK módosítása, mert abban az esetben, ha a gyermek örökbefogadóit vérszerinti szülőiként jegyezték be az anyakönyvbe, öröklési joga az eredeti, vérszerinti szülői után megszűnt, így a származás felfedésére nem kerülhet sor. Megmaradt a kettős öröklési jog akkor, ha az örökbefogadókat nem jegyezték be az anyakönyvbe vérszerinti szülőknek (1977. évi IV. tv. 617 618. $\left.\int\right)^{51}$

1867 óta a magyar királyi igazságügyminiszter erősítette meg a szerződéseket, mely nem jelentett érvényességi feltételt, csupán tanúsította, hogy a szerződés a felek akaratából köttetett, az alaki és anyagi jogszabályoknak megfelelő liquid ügylet, mely arra is szolgált, hogy harmadik személyekkel szemben tanúsítást nyerjen az örökbefogadás tényével és a névváltozás anyakönyvi bejegyzésével. A megerősítés közrendészeti szempontból volt jelentős, mert a jogügylet azért lett megerősítve, mert joghatályos örökbefogadási ügylet keletkezett a felek között. A szerződés az igazságügyminiszteri megerősítés előtt is kötötte a feleket, attól való elállást nem tett lehetôvé. Az igazságügyminiszter akkor tagadta meg a megerősítést, ha az örökbefogadás valamely törvényes

\footnotetext{
49 MESZlÉnY, Magyar Magánjog I. 706.

${ }^{50}$ MESZlÉnY, Magyar Magánjog I. 705.

${ }^{51}$ BACsÓ, Az örökbefogadás 609-616.
} 
kelléke hiányzott, vagy ha a feleknek a körülményekből nyilvánvaló akarata nem családjogi viszony alapítására irányult.. ${ }^{52} \mathrm{~A}$ megerősítés megtagadása ellen az érintettek számára egy jogorvoslati lehetőség állt nyitva: a bírói út. ${ }^{33} \mathrm{Az}$ örökbefogadó szerződés az igazságügyminiszteri megerôsítéssel lépett hatályba, melyet az igazságügyminiszter rendeleti formában adott ki. A rendelet két fő részre tagolódott: elsőként a kormányhatósági megerősítést tartalmazta, majd a közvetítő hatóságokhoz szóló utasítást - kiskorúak esetében az árvaszékhez, nagykorúaknál pedig a törvényszékhez - hogy lássák el a szerződés példányait megerősítő záradékkal, intézkedjenek az örökbefogadás ténye, a névváltozás vagy annak a ténynek az anyakönyvbe való bejegyzéséről, hogy az örökbefogadott neve nem változott, a feleket pedig az iratok egyidejü megküldésével értesítsék (213. §). ${ }^{54} \mathrm{Az}$ örökbefogadó vagy az örökbefogadott halála után megerősített szerződés csak akkor volt hatályos, ha az egyik fél az igazságügyminiszterhez vagy más közhatósághoz megerôsités/jóváhagyás végett a meghalt fél életében bemutatta vagy erre megbízást adott. (214. \).55

A levéltári kutatásaim alkalmával három esetben találkoztam azzal, hogy az igazságügyminiszter megtagadta az örökbefogadási szerződés megerősítését. Az egyik esetben a gyermek törvénytelen származásúként volt anyakönyvezve, annak ellenére, hogy házasságban született, így házassági vélelem okán, törvényes gyermekként az örökbefogadás nem jöhetett létre. ${ }^{56}$ A másik két esetben úgy szólt az örökbefogadási szerződés, hogy az „örökbefogadó átvállalja az örökbe fogadandóval szemben mindazon jogokat, melyek az atyát a törvény szerint gyermekével szemben megilletik. Ez a rendelkezés jogilag nem állhat meg, mert ide tartozik a törvényes örökösödési jog is, az örökbefogadás az örökösödés tekintetében csak az örökbefogadott javára szolgálhat." ${ }^{57}$ Illetve emellett hiányos az egyik örökbefogadási szerződés abban a tekintetben is, hogy az „örökbefogadandó a rá átruházni szándékolt családnevet saját születési családnevéhez kapcsolva vagy ez elhagyása mellett köteles és jogosult-e a jövőre nézve viselni." ${ }_{58}$

A hazai jog a felbontható örökbefogadás mellett állt, kimondta, hogy amennyiben az örökbefogadott vagy az örökbefogadó olyan cselekményt követett el, amely miatt a szülő ivadékát vagy az ivadék szülőjét kitagadhatta vagy pedig, ha az örökbefogadott vagy az örökbefogadó az örökbefogadással járó kötelességeit szándékos magaviseletével egyébként oly súlyosan megsértette, emiatt a másik félrenézve az örökbefogadás fenntartása elviselhetetlenné vált. A sértett fél az örökbefogadási szerződés megtámadására vonatkozó szabályoknak megfelelően keresettel kérhette az örökbefogadás bírói felbontását, kivéve az örökbefogadó vagy az örökbefogadott halála után, a vétkes cselekmény megbocsátása esetén. Az örökbefogadás felbontó ítélet jogerőre emelkedésének napján szűnt meg. A bíróság az örökbefogadói szerződést hatálytalanította, az örökbefogadási jogviszonyt felbontotta azon az alapon, hogy a szerződésben álló felek egyikének szándékos magatartása a másik félre nézve annyira elviselhetetlenné vált, hogy indokolt az ártatlan felett a jogviszonytól felszabadítani. Az örökbefogadói szerződés csak olyan okból hatálytalanítható, mely az örökségből való kitagadásra is elegendő. Az örökbefogadásból eredő kötelességek súlyos

\footnotetext{
52 MESZLÉNY, Magyar Magánjog I. 700-701.

53 MeSZlÉnY, Magyar Magánjog I. 703.

${ }^{54}$ MESZLÉNY, Magyar Magánjog I. 701-702.

55 MESZLÉNY, Magyar Magánjog I. 702.

${ }^{56}$ MNL BML IV. 1409.b. II-89-1899

${ }^{57}$ MNL BML IV. 1409.b. 186-1906

58 MNL BML IV. 1409.b. 186-1906
} 
megsértésének minősült a szülő- gyermek közti viszony természetében, rendeltetésében gyökerező gyermeki kötelesség oly fokú megsértése, amelyre kölcsönös elnézés, engesztelés rendes mértékét többé alkalmazni nem lehetett. Ennek minősült még a méltatlan házasság, szökés, erkölcstelen viselkedés is. ${ }^{59}$

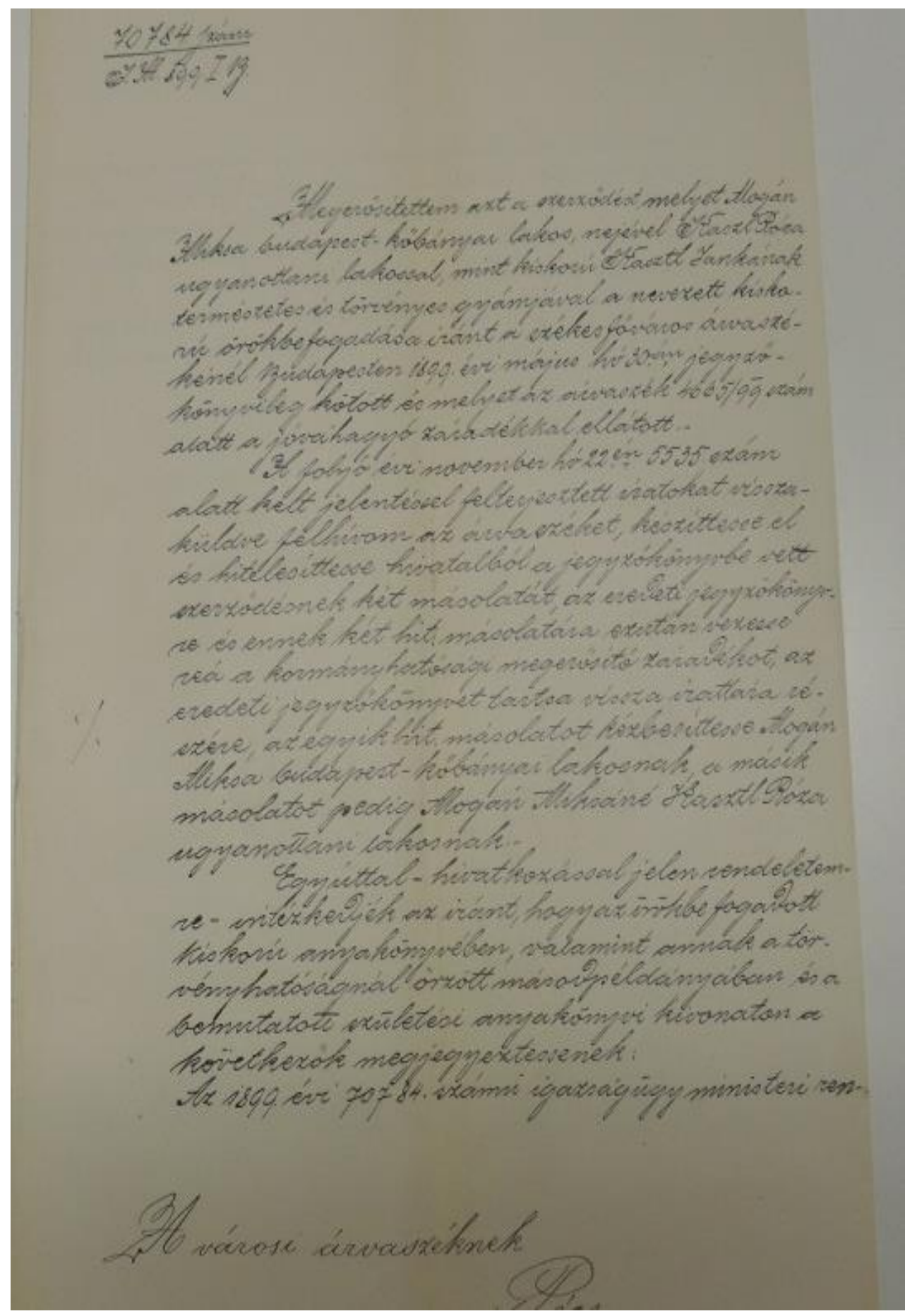

7. kép: Az örökbefogadási szerződés megerősitése a magyar királyi Igazságügyminiszter által

\footnotetext{
${ }^{59}$ MESZLÉNY, Magyar Magánjog I. 712.
} 
MNL BML IV. 1409.b. II.-617-1899 Az örökbefogadás felbontásához a törvény az igazságügyminiszter megerősítését kívánta meg. A felbontás az örökbefogadott ivadékaira akkor hatott ki, ha ahhoz ők is hozzájárultak. Közös gyermekké fogadás esetén amíg a házastársak éltek mindkét fél hozzájárulása szükséges volt a felbontáshoz. Ha a házastársak eltérő véleményen álltak a felbontást illetően, akkor az igazságügyminiszter megtagadta a megerősítést és árvaszék útján figyelmeztette a feleket, hogy a vitájukat vigyék a törvény rendes útjára (224. \$). ${ }^{60} \mathrm{Az}$ örökbefogadás megszủnése után az örökbefogadott és ivadékai nem viselhették tovább az örökbefogadó családi nevét, kivéve közös gyermekké fogadás esetét, ha az örökbefogadást az egyik házastárs halála után szerződéssel bontották fel (226. §). ${ }^{61}$

\section{A nemzetközi örökbefogadás szabályozása Magyarországon az 1940-es években}

Mintegy egy évtizeddel az MTJ illetve Mešlény összegzése után jelent meg Szladits Károly szerkesztésében a Magyar Magánjog c. sorozat első kötete, amely a nemzetközi örökbefogadással kapcsolatos jogvitákban adott útmutatót a jogalkalmazóknak. Kimondta, hogy az örökbefogadó hazai joga szerint kellett elbírálni az örökbefogadás megengedhetőségét, anyagi feltételeit, joghatásait. Az örökbefogadott korát, cselekvőképességét; az aktív örökbefogadási képességet; az örökbefogadó és az örökbefogadott egymás közti viszonyából folyó anyagi feltételeket (korkülönbség, azt, hogy szülő és törvénytelen gyermek, testvér, nagyszülő és unoka között létesülhet-e örökbefogadó szerződés), a vállalt jogok, kötelezettségek mértékét; a joghatásokat; azt, hogy a szerződés kormányhatósági megerősítésre szorul-e, az örökbefogadott hazai joga alapján bírálták el. Amennyiben a beleegyezés, jóváhagyás tekintetében az örökbefogadandó személy joga az örökbefogadó hazai jogával kollízióba került, akkor az örökbefogadandó személy hazai joga döntött az adott jogvitában. Az állami, közrendészeti szempontok nem tették kívánatossá, hogy az örökbefogadás konjukturális magánérdekeket szolgáljon, nem engedte az iparszerűséget, azt, hogy az örökbefogadó több külföldi állampolgárt örökbe fogadhasson, illetve megtagadta a megerősítést abban az esetben is, ha az örökbefogadó külföldi állampolgár volt. Kivételesen az igazságügyminiszter megerősíthette a külföldi örökbefogadó részéről kötött örökbefogadó szerződést, ha az örökbefogadó hazai állama az igazságügyminiszter intézkedését hatályosnak ismerte el; ha az örökbefogadó Magyarországon lakó, megállapíthatatlan állampolgárságú volt vagy ha a külföldi örökbefogadó hazájának törvényei szerint illetékes hatóságnál a megerősítést megkísérelte, de nem volt kieszközölhető amiatt, mert a külföldi hatóság magát a megerősítésre illetéktelennek mondta ki azért, mert az örökbefogadott külföldi, magyar honos (73. §). ${ }^{62}$

Tekintettel arra, hogy a nemzetközi örökbefogadások jelentôs része a dualizmus időszakában és a Monarchia felbomlását követően is ${ }^{63}$ színlelt jogügylet volt, mely a magyar állampolgárság megszerzésére irányult, a törvényhozó ennek tekintetében úgy rendelkezett, hogy amennyiben magyar örökbefogadó fogad örökbe külföldi gyermeket, az örökbefogadott nem szerzett magyar

\footnotetext{
60 MESZLÉNY, Magyar Magánjog I. 711.

${ }^{61}$ MESZLÉNY, Magyar Magánjog I. 713.

62 SZÁSZY, Nemzetközi magánjog, 462-464.

${ }^{63}$ Herger, A nővételtől 153.
} 
állampolgárságot, csak kedvezményes honosítás lehetôsége állt fenn. Amennyiben külföldi állampolgárságú örökbefogadó magyar gyermeket fogadott örökbe, az örökbefogadott nem vesztette el magyar állampolgárságát. Az örökbefogadó szerződés alaki érvényességét a szerződéskötés helyén és idején fennálló jog alapján, a lex loci actus kapcsolóelve szerint bírálták el (73. $\left.\int\right) \cdot{ }^{64}$

\section{5. Összegzés}

A vagyoni-öröklési jelleg az örökbefogadásból akkor tủnt el véglegesen, amikor az örökbefogadás intézményét először átfogóan szabályozta a pártállami korszak családjogi törvénykönyve 1952-ben. A CSJT-tôl az örökbefogadás egyértelmûen az elvesztett vagy hiányzó család pótlására szolgáló intézménnyé vált, amelynek célja a családi környezetet kényszerűen nélkülöző gyermekrôl való gondoskodás, az örökbefogadó részérôl pedig a gyermek utáni vágy - tehát egy érzelmi igény kielégítése. Ez a törvény szüntette meg teljes körűen a szülői felügyeleti jog átszállása nélküli adoptálást, azaz a szülői felügyelet nem maradhatott a vér szerinti szülőnél. ${ }^{65}$

A polgári társadalomban a végrendelkezési szabadság elismerése az örökbefogadás családpótló szerepét háttérbe szorította, az örökbefogadási viszony létesítését a felek megállapodására bízta, másrészt lehetővé tette nagykorú személyek örökbefogadását. Amennyiben az 1945 előtti magyar jogban az örökbefogadás gyakorlatilag alkalmasnak bizonyult a kiskorú gyermek érdekeinek biztosítására, úgy ez a házasságon kívül született gyermekek családi jogállásának bizonyos fokú rendezése terén érvényesült. Az apaság bírói megállapításának kizártsága és a törvényesítés egyéb lehetőségeinek bonyolult volta mellett az örökbefogadás révén vált lehetővé a gyermek és nemző apja közötti rokoni kapcsolat létrehozása, ezen keresztül pedig a gyermek eltartásáról való intézményes gondoskodás, ennek az utóbbi feladatnak a betöltésére az örökbefogadás természetesen csak azokban az esetekben bizonyult alkalmasnak, ahol a gyermek apjában egyébként is megvolt a gyermek felóli gondoskodásra való törekvés. ${ }^{66}$

A családnak ma is vannak olyan fontos funkció, amelyek kiegészítik mindazoknak a funkcióknak az ellátását, amelyeket az állam végez, tehát az állam és a család együttesen adja meg a biztos alapot mind ahhoz, hogy a gyermek egészséges, erkölcsös, művelt családban nôjön fel és a társadalom hasznos tagjává váljon. ${ }^{67}$

Az elmúlt évtizedek is hoztak újat az örökbefogadás társadalmi rendeltetésében: ma már az örökbefogadás elsődleges célja világviszonylatban az, hogy a családban nevelkedés biztonságát nyújtsa olyan gyermekek számára, akiknek szülei nem élnek, elhagyták őket vagy megfelelően nevelni nem képesek. ${ }^{68}$ A gyerek szempontjából az örökbefogadás előnyei a biztonságban és a pszichológiai szülőkhöz fűződő kapcsolatok folyamatosságában rejlenek. Az örökbefogadás a szülői szerep társadalmi és jogi megismerését is biztosítja. Az örökbefogadás nem utasítja el a biológiai szülők és más jelentős személyek fontosságát, biztonságot kell azonban nyújtani a gyerek

\footnotetext{
${ }^{64}$ SZÁSZY, nemzetközi magánjog 462-464.

${ }^{65}$ FÓNAGY, Az örökbefogadás https://orokbe.hu/2014/06/30/az-orokbefogadas-tortenelmi-latoszogbol

${ }^{66}$ PAP, Magyar Családi Jog, 224.; NIZSALOvSZKY, A család jogi rendjének alapjai, 293.

${ }^{67}$ BACSÓ, Az örökbefogadás 610.

${ }^{68}$ KATONÁNÉ PEHR, Az örökbefogadás 11.
} 
és örökbefogadó szülei számára, hogy a múlt eseményeit és élményeit elfogadják, megértsék és beszélhessenek azokról. ${ }^{69}$ Emellett az örökbefogadás intézménye által gyermekhez juthatnak olyan, gyermekre vágyó házaspárok, egyedülállók is, akiknek valamilyen oknál fogva nem születhet gyermekük. ${ }^{70}$

\section{Felhasznált források és irodalom}

Ideiglenes Törvénykezési Szabályok. In: MÁRKUS Dezső (szerk.): Corpus Juris Hungarici. Budapest 1896

Ausztriai általános Polgári Törvénykönyv az ezen törvénykönyvre vonatkozó, a függelékben foglalt utólagos rendeletekkel együtt, 2. hiteles kiadás, Pest 1870

Magyarország Magánjogi Törvénykönyve, a m. kir. igazságügyminiszter által 1928. március 1-én az Országgyúlés elé terjesztett törvényjavaslat. Budapest 1928

WerbŐZY István Hármaskönyve. Fordította: KOLOSvÁRI Sándor - ÓvÁRI Kelemen. In: MÁRKUS Dezső (szerk.): Corpus Juris Hungarici. Magyar Törvénytár. Budapest 1897

BACSÓ Jenő: Az örökbefogadás. Budapest 1968

BACsÓ Jenő: Az örökbefogadás. Jogtudományi Közlöny 1981/7. sz.

BÉLI Gábor: Magyar jogtörténet. Budapest - Pécs 2009

BEKE-MARTOS Judit: Az örökbefogadás - jogtörténeti megközelítésben. Családi Jog, 2009/4. sz.

CZUCZOR Gergely - FOGARASI János: A magyar nyelv szótára. Pest: Emich 1862-1874 http://mek.oszk.hu/05800/05887/cimkes.html

FÓNAGY Zoltán: Az örökbefogadás történelmi látószögből. https://orokbe.hu/2014/06/30/az-orokbefogadastortenelmi-latoszogbol

HEGEDÚs Andrea: Polgári Jog Családjog, Szeged 2014

HERGER Csabáné: A közszerzemény megosztása a paraszti népréteg körében Baranyában 1848 után. In: VARGA Norbert (szerk.): VI. szegedi jogtörténeti napok báró Eötvös József születésének 200. évfordulója alkalmából. Szeged, 2014, 67-95.

HERGER Csabáné: A nővételtől az állami anyakönyvvezetőig. A magyar házassági köteléki jog és az európai modellek. Budapest - Pécs 2006

JOBBÁGYI Gábor: Személyi és Családi Jog. Budapest 2008

KATONÁNÉ PEHR Erika: Az örökbefogadás és az örökbefogadási eljárás, Budapest 1999

KŐRÖS András (szerk.): A családjog kézikönyve I., Budapest 2007

MESZLÉNY Artúr: Magyar Magánjog I. Budapest 1931

NIZSALOVSZKY Endre: A család jogi rendjének alapjai, Budapest 1963

ORTUTAY Gyula (főszerk.): Magyar néprajzi lexikon (MNL), Budapest, 1977-1982 http://mek.oszk.hu/02100/02115/html/4-303.html

PAP Tibor: Magyar Családi Jog- Budapest 1967

SMITH, Carole R.: Örökbefogadók és nevelőszülők. Budapest 1995

SCHWAB, Dieter: Familenrecht. München 1989

SZÁSZY István: Magyar nemzetközi magánjog. In: SZLADITS Károly (szerk.): Magyar Magánjog I. Budapest 1941, 374 476.

SZỨCS LÁSZLÓNÉ SISKA Katalin: Az árvaszékek története és jogi szabályozása Szabolcs megyében 1848-1880 között. PhD értekezés, Miskolc 2000

VÉKÁs Lajos: Az osztrák Polgári Törvénykönyv hatása a magánjog fejlődésére. In: RÁCZ Lajos (szerk.): A németosztrák jogterület klasszikus magánjogi kodifikációi, Tanulmányok az OPTK és a BGB évfordulói alkalmából, Budapest 2011, 21-33.

${ }^{69}$ SMITH, Örökbefogadók és nevelőszülők 155.

${ }^{70}$ KATONÁNÉ PEHR, Az örökbefogadás 11. 
WEISS Emilia: Az örökbefogadás néhány társadalmi és jogi kérdése, Magyar Tudomány 1997/2.

ZÁмBÓ Géza: A gyámhatóságok, árvaszékek szervezete, eljárása a kiegyezés után, 2014 http://jesz.ajk.elte.hu/zambo16.html\#_ftn20 